\title{
Brazilian Bioluminescent Beetles: Reflections on Catching Glimpses of Light in the Atlantic Forest and Cerrado
}

\author{
ETELVINO J.H. BECHARA and CASSIUS V. STEVANI \\ Departamento de Química Fundamental, Instituto de Química, Universidade de São \\ Paulo, Av. Prof. Lineu Prestes, 748, 05508-000 São Paulo, SP, Brazil
}

Manuscript received on July 4, 2017; accepted for publication on August 11, 2017

\begin{abstract}
Bioluminescence - visible and cold light emission by living organisms - is a worldwide phenomenon, reported in terrestrial and marine environments since ancient times. Light emission from microorganisms, fungi, plants and animals may have arisen as an evolutionary response against oxygen toxicity and was appropriated for sexual attraction, predation, aposematism, and camouflage. Light emission results from the oxidation of a substrate, luciferin, by molecular oxygen, catalyzed by a luciferase, producing oxyluciferin in the excited singlet state, which decays to the ground state by fluorescence emission. Brazilian Atlantic forests and Cerrados are rich in luminescent beetles, which produce the same luciferin but slightly mutated luciferases, which result in distinct color emissions from green to red depending on the species. This review focuses on chemical and biological aspects of Brazilian luminescent beetles (Coleoptera) belonging to the Lampyridae (fireflies), Elateridae (click-beetles), and Phengodidae (railroad-worms) families. The ATPdependent mechanism of bioluminescence, the role of luciferase tuning the color of light emission, the "luminous termite mounds" in Central Brazil, the cooperative roles of luciferase and superoxide dismutase against oxygen toxicity, and the hypothesis on the evolutionary origin of luciferases are highlighted. Finally, we point out analytical uses of beetle bioluminescence for biological, clinical, environmental, and industrial samples.
\end{abstract}

Key words: Coleoptera, bioluminescence, luciferase, luciferin, luminous termitary, oxidative stress.

\section{INTRODUCTION}

Bioluminescence is defined as visible and cold light emission by living organisms. It results from the oxidation of a substrate called luciferin by molecular oxygen catalyzed by an enzyme named luciferase, leading to a singlet excited-state product

Correspondence to: Etelvino José Henriques Bechara E-mail: ejhbechara@gmail.com

* Contribution to the centenary of the Brazilian Academy of Sciences. (oxyluciferin*), which decays to the ground state emitting fluorescence (Shimomura 2012, Wilson and Hastings 2013). Thus, bioluminescence results from conversion of chemical energy into photons:

$$
\begin{gathered}
\text { Luciferin }+\mathrm{O}_{2} \text { (luciferase) } \rightarrow \text { Oxyluciferin* } \rightarrow \\
\text { Oxyluciferin }+ \text { Light }
\end{gathered}
$$

This review concerns about 30 years of investigation on several species of Brazilian bioluminescent beetles (Coleoptera), mainly 
click-beetles (Elateridae) and railroad-worms (Phengodidae) found in the Brazilian Atlantic Forest and the Cerrado biome. During the rainy season, after sunset, bright and multicolored light flashes emitted by flying beetles (Coleoptera) offer a magnificent visual spectacle (Bechara 1988, Bechara and Viviani 2015). Not surprisingly, how and why these worldwide distributed insects emanate intense and cold light are questions that have awakened the curiosity of ordinary people, writers, philosophers and scientists since ancient times (Harvey 1957). Impressed by the intense flashes of light sparked by the firefly at night, Machado de Assis, a renowned Brazilian writer wrote the sonnet Círculo Vicioso (Vicious Circle) where a whispering chain of firefly, star, moon, and the sun envy the brighter one, and finally the sun, feeling itself too radiant and hot, wishes to be a simple firefly. The sonnet 'jealous' insect aspires to be able to chemically produce as much energy as the nuclear forces of the stars, being orders of magnitude higher.

Dancing in the air, moaned a restless firefly:

"Oh, would that I could be that star so yellow

Shining in the everlasting blue, as a candle mellow!"

But the star gazed at the moon with envy high:

"If only I could copy thy wondrous silver light, That from column Greek to Gothic window-case Hath gazed with longing on my beloved's face!"
Yet the moon turned to the sun, full of spite:

"Wretch! I would have thy clarity overwhelming Shining immortal, all light joined in one!" Replied the Sun, his shining crown bending:

"Weary am I of this halo of luminous sky This light and boundless canopy weighs heavy. Oh, that I were born a humble firefly!"

Vicious Circle, Machado de Assis (Courtesy free translation by Clara Allain)

In fact, an attentive onlooker would soon realize that the beetles, swirling in their glimmering cloud, are caught up in their nuptial flight. Afterwards, the insects pose on leaves and grass for copulation. In Brazil, the occurrence of fireflies and other luminous insects was first registered by Gabriel de Souza in 1587 in a document to Felipe I, King of Portugal and Spain, describing "mamoás" (fireflies) and "buijejas" (probably, railroad-worms) so called by the Amerindians of the State of Bahia (Moraes 1940). Fireflies (Lampyridae), click-beetles (Elateridae) and railroad-worms (Phengodidae) constitute the three most abundant families of luminescent coleopterans in Brazil (Fig. 1).

Until present days, elucidation of the biochemical mechanism of a given luminescent organism, be it a fly (Viviani et al. 2002) or a mushroom (Oliveira and Stevani 2009), frequently employs the preparation of a "hot" extract by heatinduced enzyme denaturation: the initial step of the basic protocol long established by Raphael Dubois

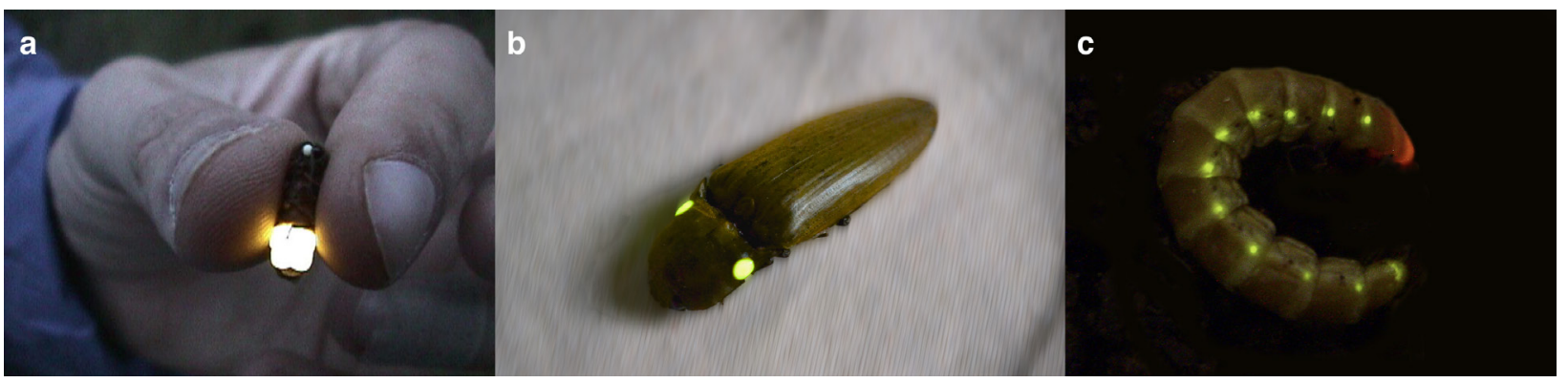

Figure 1 - Photographs of a firefly (Macrolampis omissa) (a), a click-beetle (Pyrophorus sp.) (b), and a railroad-worm (Phrixothrix hirtus) (c). 
(1886) when studying the basic ingredients for light emission by a click-beetle, formerly named Pyrophorus noctilucus. Dubois mixed "cold" and "hot" aqueous extracts of the insect lanterns and discovered that a thermostable substrate (luciferin) and a thermolabile component (luciferase) elicit a flash of green light. Much later, McElroy (1947) discovered that addition of ATP and $\mathrm{Mg}^{2+}$ ions is also necessary to enhance the in vitro and in vivo firefly bioluminescence. Success of the Dubois experiment with any bioluminescent organism also depends on molecular oxygen, a requirement discovered by Robert Boyle (1668a, b) when comparing the luminescence of decomposing fish (actually bacteria) and rotten wood (from saprophytic fungi) under 'vaccum' (sic) and air. He also differed the nature of the flame of burning coal (hot) from the shining wood (cold), both oxygendependent phenomena.

Hundreds of marine fishes, jellyfishes, squids, mollusks, sea stars, crustaceans, annelids, in addition to bacteria and dinoflagellates, have been found to be luminescent, although the chemical mechanisms of many of them had yet to be revealed. Terrestrial luminescent organisms are less diversified, among them being beetles, flies, fungi, and millipedes. In general, bioluminescence serves intra- and interspecies communication in mating, predation, camouflage, and grouping. Not obvious is the role of bioluminescence in bacteria, dinoflagellates, fungi and other beings in lower branches of the evolutionary tree. Recently, comparative experiments with luminous mushrooms and green LED-illuminated artificial acrylic 'mushrooms' were shown to equally attract several classes of flying insects, which do not feed on the fungi but carry spores on the legs thereby dispersing them on the vegetation (Oliveira et al. 2015). Also noteworthy is the concept of generegulated bacterial quorum sense presented by nonluminous bacteria when dispersed in the ocean or immediately after inoculated in a growth medium but glowing with the increase of bacterial density in the luminogenic organ of certain fishes or in the culture plate during the exponential growth. This results from the accumulation of an auto-inducer in the medium, which induces the luciferase biosynthesis.

It is believed that the acquisition of bioluminescence occurred discontinuously at least 30 times along the evolution, on the basis of the varied luciferase structures, enzymatic mechanisms and luciferin nature clarified until now in distant luminous organisms. Kaskova et al. (2016) listed nine luciferins identified up to the present: FMNH/ long chain aldehyde in bacteria (Alivibrio fisheri), linear tetrapyrrole in dinoflagellates (Lingulodinium polyedra, formely Goniaulax), hispidin in fungi, an aliphatic formylenol in a clam (Latia luciferin), two imidazopyrazines in crustaceans (Vargula, formerly Cypridina luciferin) and coelenterates (Renilla and Aequorea luciferin), a $N$-isovaleryl3-aminopropanal in the earthworm Diplocardia, a peptide in another earthworm (Fridericia), and a benzothiazolyl thiazole in coleopterans (Fig. 2). Luciferins of the blue-emitting flies Arachnocampa (New Zealand) and Orphelia (United States of America) are still under investigation (Viviani et al. 2002).

Additionally, the reaction mechanisms of bioluminescent systems follow distinct patterns of complexity. The bioluminescent system of the crustacean Vargula higendorfii (Cypridinidae) is the simplest one. It requires only luciferin, luciferase, and oxygen for light emission, whereas that of firefly lanterns also depends on ATP to activate the substrate (McElroy 1947, Wilson and Hastings 2013). In Renilla reniformis, the luciferase is associated with another protein (Green Fluorescent Protein, GFP) before reacting with its luciferin, named coelenterazine, whose excited product (coelenteramide) directly transfers energy to GFP, discharging green light emission $\left(\lambda_{\max } 509\right.$ $\mathrm{nm})$. In vitro, in the absence of GFP, the luciferin/ 


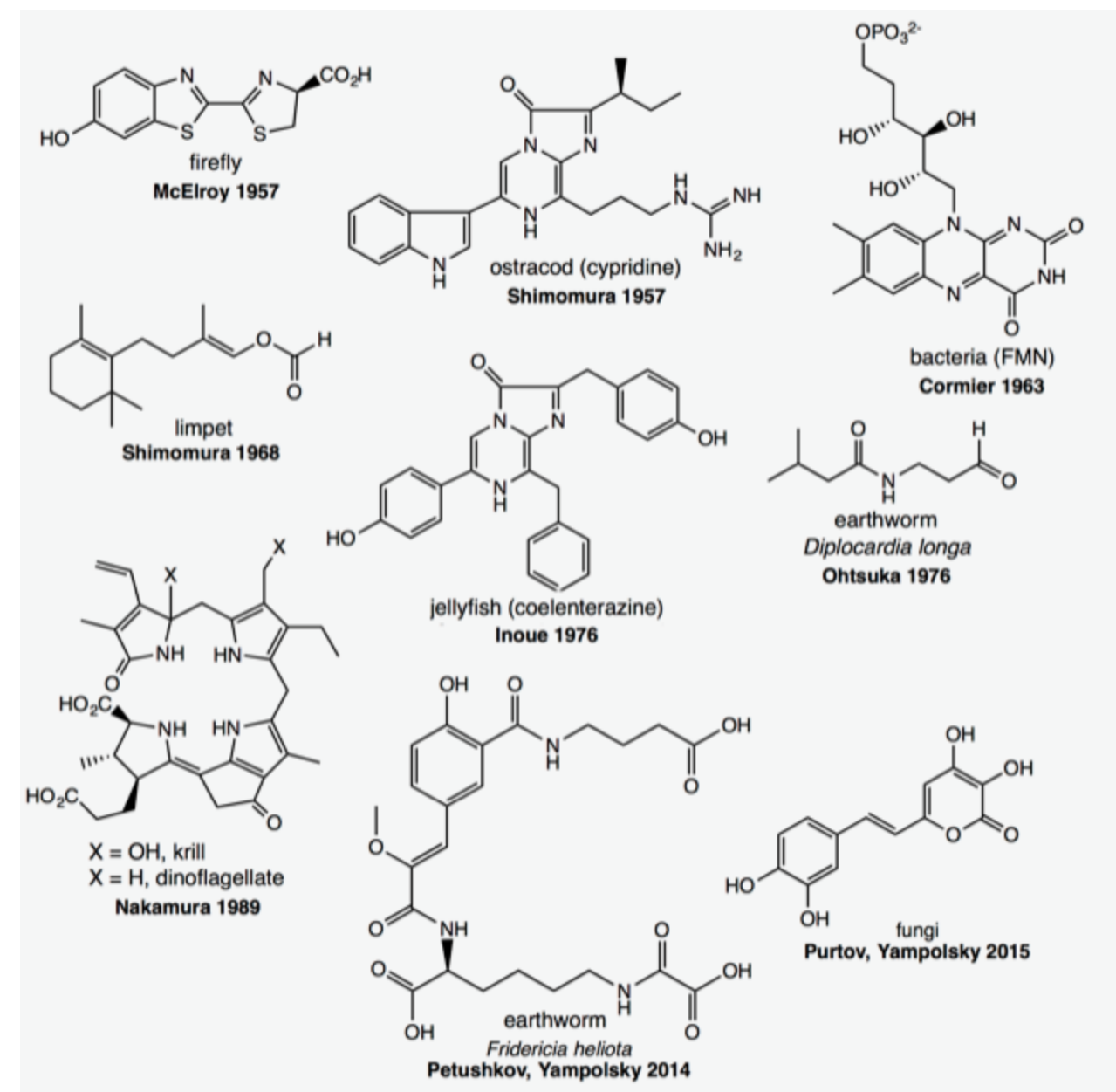

Figure 2 - Molecular structure of the luciferins identified in marine and terrestrial bioluminescent organisms. Modified from Kaskova et al. (2016).

luciferase system of Renilla releases blue light $\left(\lambda_{\max }\right.$ $480 \mathrm{~nm})$. The jellyfish Aequorea victoria prepares and stores a stable complex luciferase-luciferinoxygen, called aequorin, that immediately emits GFP green flash $\left(\lambda_{\max } 509 \mathrm{~nm}\right)$ upon addition of $\mathrm{Ca}^{2+}$ ions. Fungal luminescence has recently been shown to be more complicated: The actual substrate is 3-hydroxyhispidine prepared from hispidin in the presence of a NAD(P)H-dependent hydroxylase before reacting with luciferase/oxygen to glow $\left(\lambda_{\max } 530 \mathrm{~nm}\right)$, and the reaction mechanism implies a single electron transfer process not yet deciphered.

\section{LUMINESCENCE BEETLES: CHEMISTRY AND COLOR MODULATION}

The three main families of Brazilian adult species of luminescent coleopterans, although emitting colors spanning from green (thoracic lanterns, $\lambda_{\max } 525$ $\mathrm{nm}$ ) in Pyrearinus candens (Elateridae), yellow in Macrolampis omissa (abdominal lantern, $\lambda_{\max \sim} 572$ $\mathrm{nm})$ (Lampyridae), to red (cephalic lanterns, $\lambda_{\text {max }}$ $620 \mathrm{~nm}$ ) in Phrixothrix viviani (Phengodidae), share the same luciferin and surely the same reaction mechanism (Colepicolo-Neto et al. 1986a, Viviani and Bechara 1995, 1997).

Most structural and mechanistic studies about the firefly light reaction were conducted 
with the North American firefly Photinus pyralis (Lampyridae). Firefly luciferin was first isolated and partially identified by Bitler and McElroy (1957) as a benzothiazoyl-thiazole, and its structural determination and synthesis later accomplished by White et al. (1963). That elaterid luciferin is biosynthesized from cysteine was qualitatively confirmed by McCapra and Razavi (1976) in adult Pyrophorus pellucens administered $\mathrm{L}-{ }^{14} \mathrm{C}$-cystine and was further corroborated in a time- and $\mathrm{L}_{-}{ }^{35} \mathrm{~S}$ Cys-concentration dependent fashion in larval Pyrearinus termitilluminans (Colepicolo et al. 1988). Later, 2-cyano-6-hydroxy benzothiazole was shown to condense with two molecules of ${ }^{13} \mathrm{C}$-labeled L-Cys molecules, to yield biologically active labeled D-(-)-luciferin in the adult lanterns of Luciola lateralis (Lampyridae) (Oba et al. 2013).

Studies of the Photinus pyralis luciferin/ luciferase reaction from 1956 to 1976 by McElroy and DeLuca (1978, and ref. therein) supported the following basic steps for light emission:

$$
\begin{gathered}
\mathrm{Enz}+\mathrm{LH}_{2}+\mathrm{Mg}^{2+} \mathrm{ATP} \rightarrow \text { Enz-LH } \\
+\mathrm{Mg}_{2}^{2+}-\mathrm{AMP}+\mathrm{PP} \\
\text { Enz-LH } \mathrm{H}_{2}-\mathrm{AMP}+\mathrm{O}_{2} \underset{\mathrm{AMP}}{\rightarrow} \mathrm{Enz}+\mathrm{LO}^{*}+\mathrm{CO}_{2}+ \\
\mathrm{LO}^{*} \rightarrow \mathrm{LO}+\text { light }
\end{gathered}
$$

where Enz is the enzyme (luciferase); $\mathrm{LH}_{2}$, reduced luciferin; PP, pyrophosphate; and LO*, electronically excited oxyluciferin.

Later, White et al. (1963) detailed the putative mechanism of the firefly reaction, where the chemiexcitation step is the cleavage of an energyrich peroxide intermediate to yield $\mathrm{CO}_{2}$ and excited oxyluciferin (Figure 3).

Luciferase first acts as a ligase at costs of ATP to activate the luciferin carboxylic group as a luciferyl-adenylate anhydride (Fig. 3, 1) and sequentially as an oxygenase by inserting molecular

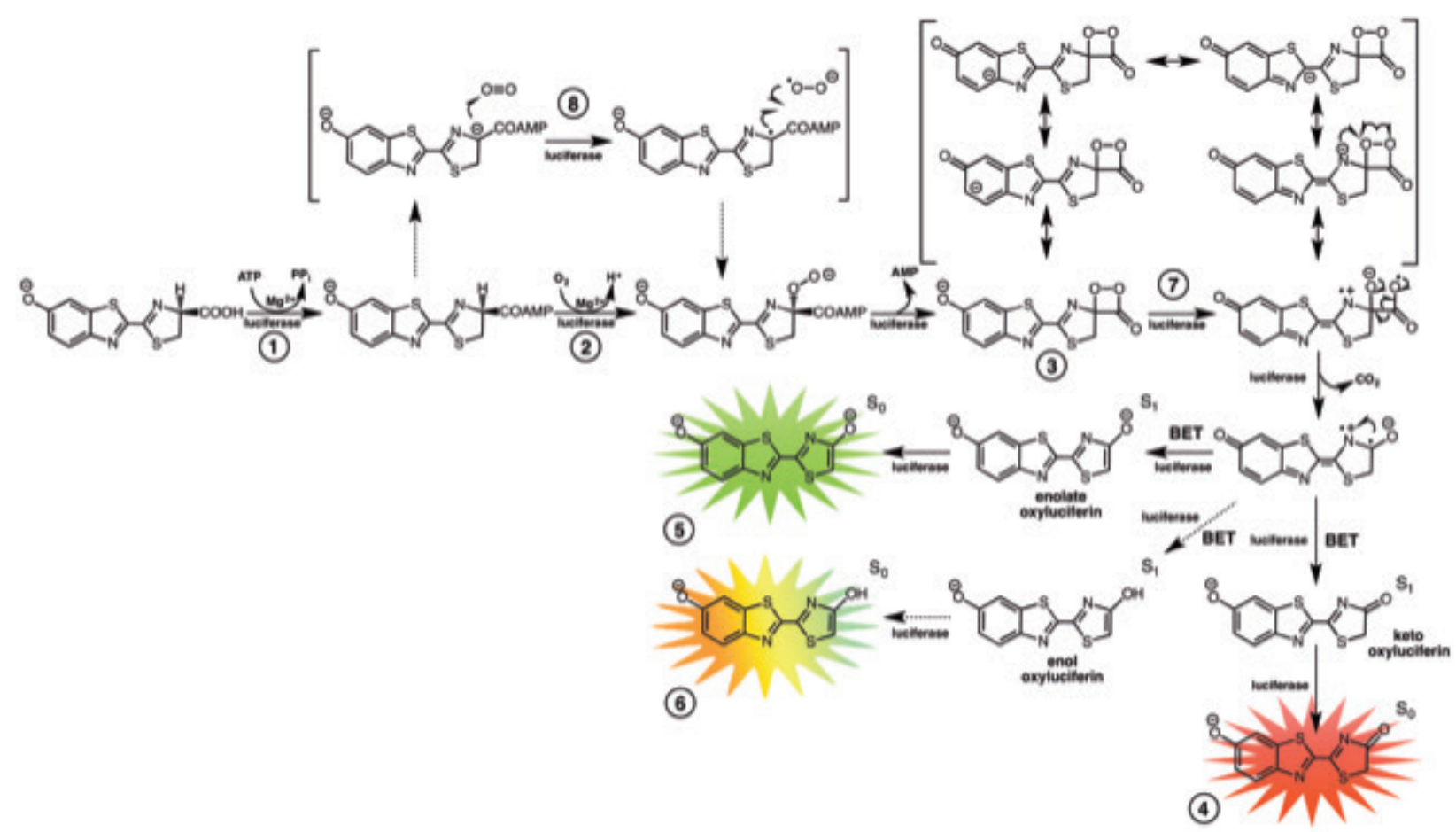

Figure 3 - Detailed mechanism of firefly luciferin oxidation and chemiexcitation catalyzed by luciferase. BET, back electron transfer. 
oxygen into the luciferin $\alpha$-carbanion to form an $\alpha$-hydroperoxide (Fig. 3, 2). This intermediate then undergoes cyclization with release of AMP to a putative four-membered ring peroxide (Fig.3, 3), named $\alpha$-peroxylactone or dioxetanone (Bartoloni et al. 2015, Bastos et al. 2017), whose cleavage (Fig. $3,7)$ yields $\mathrm{CO}_{2}$ and the oxyluciferin in the excited singlet, fluorescent state (Fig. 3, 4-6) (Shimomura et al. 1977, Oba et al. 2003). The topology of the luciferase active site is importantly affected by (i) the $\mathrm{pH}$ in lampyrid luciferases, but not in elaterids and phengodids (Viviani and Bechara 1995); (ii) the polarity of the microenvironment; and (iii) the luciferin binding and catalytic amino acids which may favor formation of the excited oxyluciferin either in its red $\left(\lambda_{\max } \sim 615 \mathrm{~nm}\right)$ monoanion keto form (Fig. 3,4$)$ and green $(540 \mathrm{~nm})$ dianion enolate form (Fig. 3, 5) (Shimomura 2012, Viviani et al. 2012). These facts led to the belief that an important basic amino acid residue like arginine present, distant or absent near the nascent excited oxyluciferin assists the formation of the keto or enolate product.

Methylation of the luciferin phenol moiety abolishes the bioluminescence, thereby indicating that the actual substrate is the luciferin phenolate anion attracted by a critical amino acid at the active site.

Luciferase was first crystalized from Photinus pyralis by Green and McElroy (1956). Today we know that purified beetle luciferases do not contain any co-factor or prosthetic group, and their molecular weight is 60 to $61 \mathrm{kDa}$. All luciferases have 542 to 550 amino acid residues and catalyze the same reaction; however, their similarity with that of P. pyralis varies from $82 \%$ in Pyrocoelia miyako (Lampyridae) down to $46 \%$ in Pyrophorus plagiophthalamus (Elateridae) (Viviani 2002).

That a luciferin-derived dioxetanone is the energy-rich intermediate involved in the chemiexcitation step of the reaction (Fig. 3) was firmly established by even incorporation of ${ }^{18} \mathrm{O}$ in the oxyluciferin and $\mathrm{CO}_{2}$ via experiments with ${ }^{18} \mathrm{O}_{2}$. The expected oxygen exchange of labeled products with regular $\mathrm{H}_{2}{ }^{16} \mathrm{O}$ was corrected by performing double labeling experiments with ${ }^{18} \mathrm{O}_{2}$ and $\mathrm{H}_{2}{ }^{17} \mathrm{O}$ (Shimomura et al. 1977).

The chemiexcitation step of the light reaction, first thought to result from direct cleavage of the luciferin-derived dioxetanone to oxyluciferin and $\mathrm{CO}_{2}$ (Adam and Liu 1972), was later shown by Koo et al. (1978) to be initiated by electron transfer from its phenolate moiety to the dioxetanone ring. The resulting unstable diradical then undergoes cleavage and back electron transfer (BET), yielding excited oxyluciferin and $\mathrm{CO}_{2}$ (Fig. 3, 7 towards 4-6). This kind of chemiexcitation mechanism was coined chemically initiated electron exchange luminescence (CIEEL) and found to operate in several chemi- and bioluminescent systems, either intramolecular from peroxides carrying a substituent with low oxidation potential, or bimolecular if initiated by a good electron donating activator (Fig. 4).

Despite being the first luciferin/luciferase system described in Photinus pyralis by McElroy and DeLuca (1978, and ref. therein), it leaves more questions to be answered. A fundamental one is the mechanism of luciferin oxidation by molecular oxygen to produce singlet excited oxyluciferin and ground state $\mathrm{CO}_{2}$. This reaction is spin forbidden, and the luciferase is cofactor-independent, i.e., no metal or redox active cofactor is present. Recently, Branchini et al. (2015) suggested that the spinforbiddeness could be circumvented by previous single electron transfer from the luciferin carbanion to $\mathrm{O}_{2}$, yielding a resonance stabilized luciferin radical and the superoxide anion radical $\mathrm{O}_{2}{ }^{--}$, which would counter-attack the luciferin radical to produce a cysteine thiolate-assisted hydroperoxide anion, the precursor of the hypothetic dioxetanone intermediate (Fig. 3, 8). The authors' proposal relied on a model EPR spin-trapping study of $\mathrm{O}_{2}{ }^{--}$radical with 5-tert-butoxycarbonyl 5-methyl-1-pyrroline$\mathrm{N}$-oxide (BMPO), in sodium phenolate-contained dimethyl sulfoxide as the solvent. The superoxide 


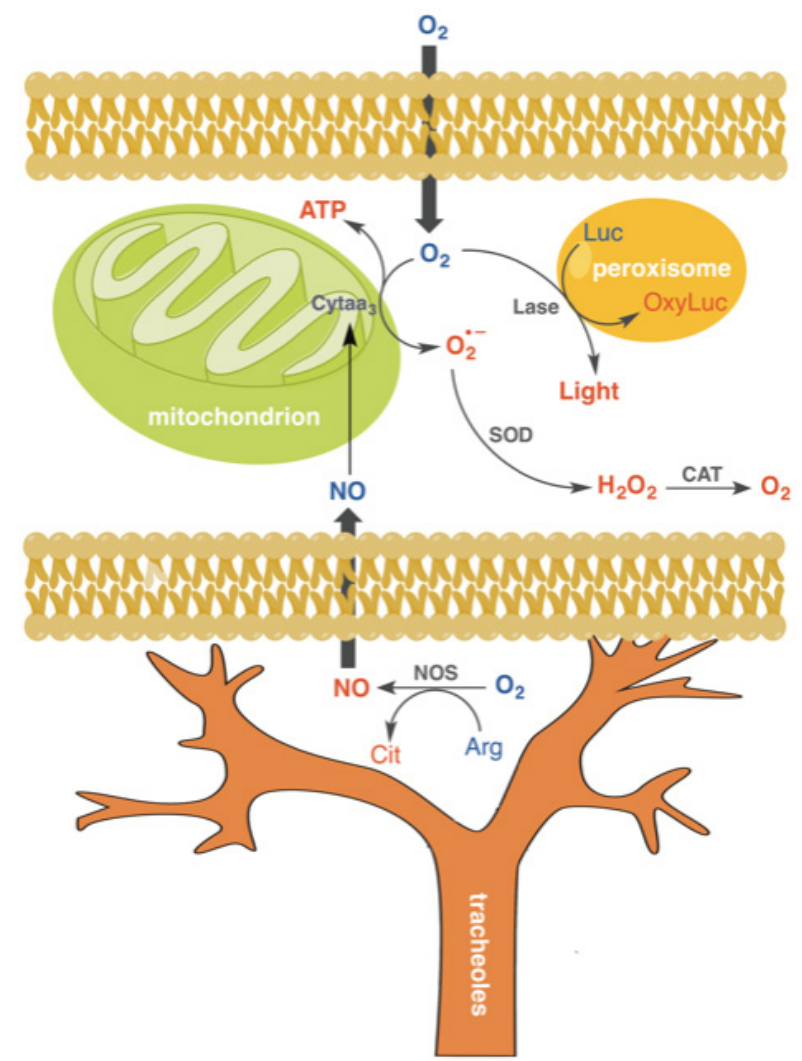

Figure 4 - Interplay of molecular oxygen $\left(\mathrm{O}_{2}\right)$, nitric oxide (NO) and luciferin in firefly flashing. Sexual stimulus releases the neurotransmitter octopamine, which ultimately activates the nitric oxide synthase (NOS) in the tracheole terminals. The NO gas diffuses across the photocyte membrane, reaches the mitochondria, binds to the cytochrome oxidase complex $\left(\mathrm{Cyt} \mathrm{aa}_{3}\right)$ and inhibits the respiratory chain leading to a sudden increase of $\mathrm{O}_{2}$ concentration. The instantaneous excess of $\mathrm{O}_{2}$ in the photocyte triggers oxygen consumption by luciferin (Luc), catalyzed by luciferase (Lase) in the peroxisome membrane creates excited oxyluciferin (OxyLuc) and the firefly lantern flickers. Arg, arginine; Cit, citrulline; SOD, superoxide dismutase; CAT, catalase.

anion radical was shown to be produced by oneelectron transfer from luciferin methyl ester to the dissolved oxygen. The annihilation of a radical pair luciferin $-\mathrm{O}_{2}{ }^{--}$would supposedly precede the luciferin hydroperoxide intermediate.

\section{THE MULTICOLOR NUPTIAL DANCE OF LUMINESCENT BEETLES}

The firefly flashing is a response to sexual attraction and mating; hence, it is under neurological control. Trimmer et al. (2001) demonstrated that the insect neurotransmitter octopamine triggers activation of nitric oxide synthase in the terminal tracheloles of fireflies, interposed between nerve endings and the light-producing photocytes (Fig. 4). The pulsed nitric oxide (NO'), a diffusible gas, reaches the lantern mitochondria where it binds to cytochrome oxidase, causing short-lasting (milliseconds) inhibition of the respiratory chain. The sudden local increase of oxygen would then spark the flash and restore oxygen consumption and ATP production. How this mechanism explains induction of NO synthase, the temporary lack of ATP to sustain the bioluminescent reaction, the reactivation of cytochrome oxidase, and the continuous light emission by larval fireflies, adult elaterids and phengodids, demands more research on the physiology of luminescent insects (Bechara et al. 2017).

Over the last three decades, during the period of September to December, we observed clouds of fireflies and click-beetles just after sunset in the Atlantic Forest and in the Cerrados of Central Brazil and collected tens of different species to trace their emission spectra in the laboratory and investigate several aspects of their biochemistry. The lanterns of adult and larval fireflies are in the tail. Yellow light is emitted by early species, in the twilight, probably to be distinguished by their sexual partners in the vegetal photic environment, whereas other species shine yellow-green only after sunset. In all cases, the flash color (550-580 $\mathrm{nm}$ ), intensity, duration (miliseconds), frequency (1-10 $\left.\mathrm{s}^{-1}\right)$ and flight pattern are species-specific. Larval fireflies posed on meadow grass glow continuously to attract prey but are also often seen captured by spider webs. Lloyd (1978) described several patterns of American firefly flickering during sexual courtship, including their mounting positions. Flying Lampyrid males respond to the signals of their partners posed on the grass; Photinus, Aspisoma and Luciola flying males 
flash to the females, which respond and approach them for mating; thousands of male Pteroptyx, in Southeast Asia, congregate on the branches of trees and synchronize their flashes to optimize the attraction of females. In a nefarious twist, Photuris females mimic the female signals of other species only to attract and devour their males (Lloyd 1978).

According to Costa (1997), Brazil is home c.a. $18 \%$ (350) of the lampyrid species reported by the international literature, 6\% (590) of elaterids, and $20 \%$ of phengodids. Adult elaterids possess two lanterns placed laterally on the dorsal prothorax, shining green light for a couple of minutes when at rest, handled or walking, and an orange-emitting light organ in a cleft of the first abdominal segment, which is intermittently exposed during flight when chasing females on the leaves. Our biochemical studies of elaterids cover 12 species collected in the proximities of the National Park of Emas (State of Goiás) and in Atibaia, Billings Reservoir, and Cantareira State Park (State of São Paulo): 3 Pyrophorus spp, 6 Pyrearinus spp., 1 Opselater sp., and 2 Hapsodrilus spp. (Colepicolo-Neto et al. 1986a). The maximal spectral intensity of their in vivo luminescence ranged 525 (Pyrearinus candens) to $550 \mathrm{~nm}$ (Pyrearinus termitilluminans and Opselater pyrophanus) from the prothoracic lantern; and 562 (Pyrophorus divergens and P. candens)-584 nm (H. ignifer) from the abdominal light organ. The in vivo and in vitro spectra measured in Tris buffer $\mathrm{pH} 8.2$ were similar within the experimental error as well as the male and female light emissions. Eggs, larvae and pupae of $P$. termilluminans and a few other elaterid species were also shown to be luminescent. According to Niwa et al. (2010), the more blueshifted the bioluminescence spectrum of lampyrids, elaterids and phengodids, the higher the quantum yield of light emission is. Among all beetle species studied, Pyrearinus termitilluminans was the one to discharge the greenest light and to show the highest efficiency of light emission $(60 \%)$, thanks to its prothoracic lanterns.
The happenings surrounding the sexual attraction and mating of adult elaterids as well as the reasons immobile eggs and pupae shine still await investigation. When collecting Pyrophorus divergens in the Atlantic Forest, just after sunset, we often observed an aerial raid of yellow lights for $20 \mathrm{~min}$ over the vegetation, where females were shining their green prothoracic lantern, most likely signaling to the flying males. Elaterid couples copulating on the leaves could be caught after the nuptial flight.

The role of bioluminescence in the intraspecific sexual communication in lampyrids and elaterids is supported by the observed correspondence between their broad-spectrum emission and their retina sensitivity (Lall 1981, 2010). Accordingly, the electroretinographic trace of Pyrophorus punctatissimus matched almost totally the emission spectrum of its green lanterns and partially the orange one (Lall et al. 2000). This obviously means that the luminescent beetles do see the emitted light.

Phengodids are unique in terrestrial bioluminescence: they can simultaneously radiate two colors. Several phengodid species displaying distinct pairs of emission colors were collected near the National Park of Emas, and among them were yellow-emitting Brasilocerus impressicollis (larva, $\lambda_{\max } 550$ and $565 \mathrm{~nm}$ ), orange-emitting Mastinocerus sp. (larva, $\lambda_{\max } 577$ and $597 \mathrm{~nm}$ ), and red-emitting Phrixothrix hirtus (larva, $\lambda_{\max }$ 563 and $609 \mathrm{~nm}$ ) (Viviani and Bechara 1997) (Fig. $5)$. Three new species found in that region were collected and further described by Wittmer (1996): Phrixothrix viviani, Euryopa clarindae, and E. laurae.

Phrixothrix viviani larvae emit green light $\left(\lambda_{\text {max }}\right.$ $\sim 542 \mathrm{~nm}$ ) from eleven pairs of lanterns disposed dorso-laterally along the abdomen and red light $\left(\lambda_{\max } \sim 620 \mathrm{~nm}\right)$ from a lantern located on the head. The yellow-green lateral $\left(\lambda_{\max } \sim 542 \mathrm{~nm}\right)$ and red cephallic $\left(\lambda_{\max } \sim 628 \mathrm{~nm}\right)$ luciferases of Phrixothrix 

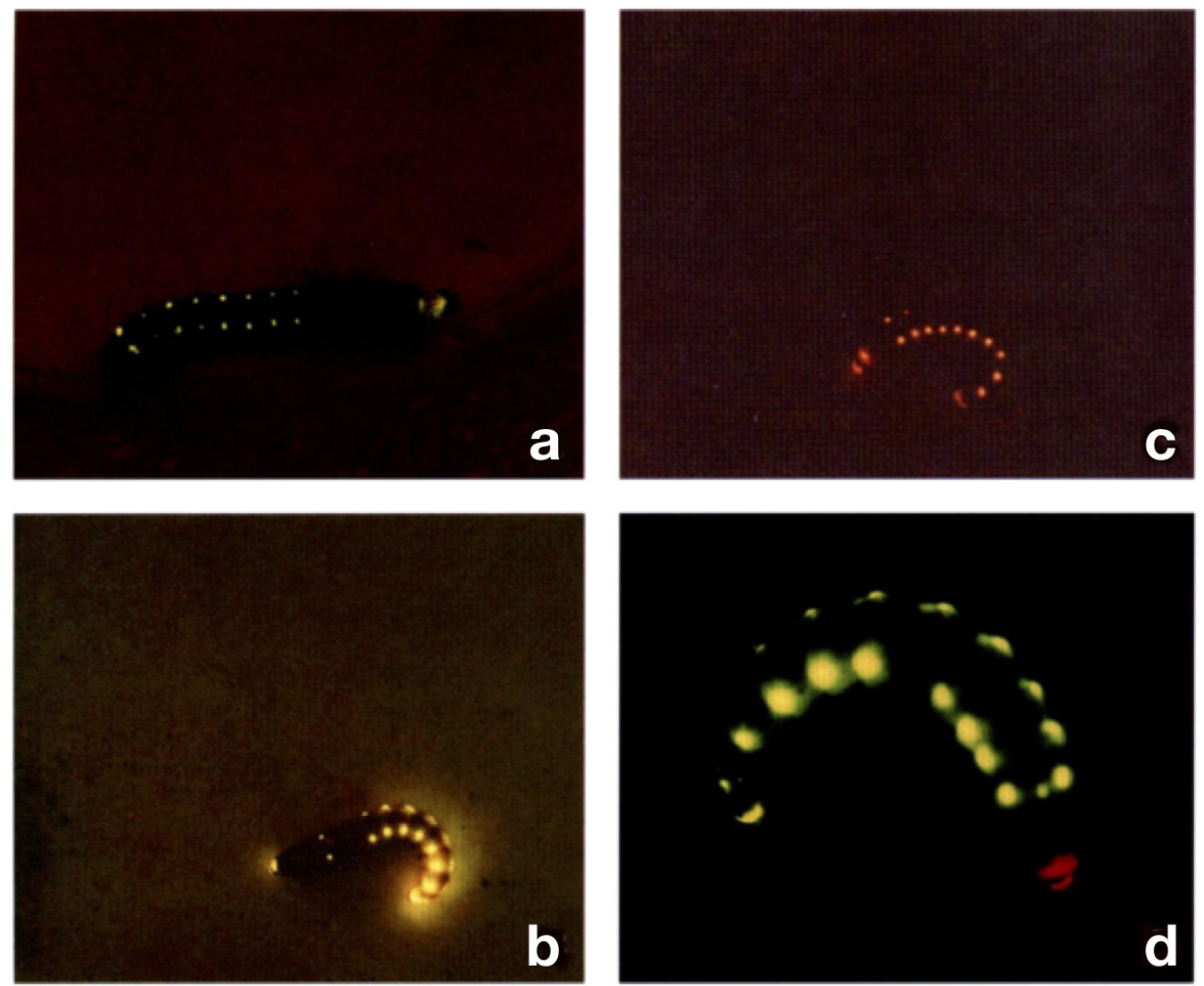

Figure 5 - Phengodids glowing: (a) Mature larval Brasilocerus impressicollis (2-3 cm long); (b) Larviform female Mastinocerus $\mathrm{sp}_{1}$. (1.5-2 cm long); (c) Larval Mastinocerus $\mathrm{sp}_{2}(1.5-2 \mathrm{~cm}$ long); (d) Mature larval Phrixothrix heydeni (4-5 cm long). Pictures taken using Ektachrome 400 ASA film (d) and 100 ASA film (a-c). Reproduced from Bechara and Viviani (2015). Copyright 2014 Oxford University Press.

heydeni were cloned and expressed in two E. coli colonies (Viviani et al. 1999) peaking at similar wavelengths within the experimental error: 549 and $622 \mathrm{~nm}$, respectively (Fig. 6). The bioluminescence spectral characteristics of $P$. heydeni can also be correlated with the optical signals of its yellowgreen and red lanterns (Lall et al. 2009).

Female phengodids walk sinuously on the ground with all lanterns on like an old locomotive on a railroad track at night, hence their name railroad-worms. Sharp sexual dimorphism turns complicated to collect and identify these insects in the field: female phengodids are aptera and larviform (2-5 cm long) and males are tiny $(<2$ $\mathrm{cm}$ long) and winged. Male and female Phrixothrix hirtus were raised in the lab from fertilized eggs to further described the whole life cycle (Costa et al. 1999). Red, green or both lights can be specifically displayed, but their biological roles sexual attraction, illumination for spotting preys, aposematism - require further investigation. Field observations pointed to red illumination by Phrixothrix spp. to localize preys and yellow green lights for mating.

\section{THE LUMINOUS TERMITE MOUNDS}

During the rainy season, between October and December, the twilight switches on hundreds of tiny green lights sprinkled on the surface of thousands of termite mounds (Fig. 7). Close examination 

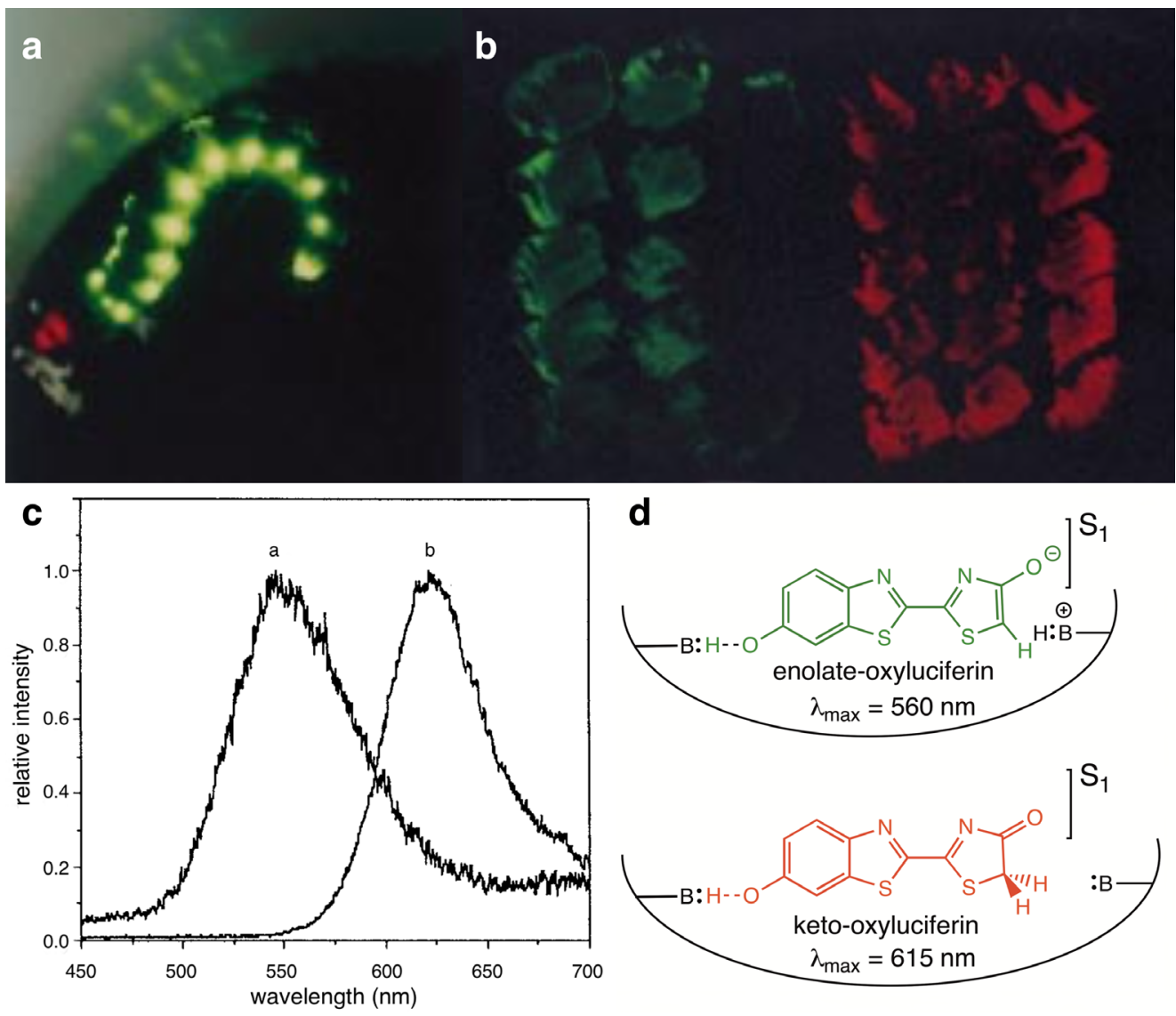

Figure 6 - Color modulation by the abdominal yellow-green and cephalic red lanterns of Phrixothrix heydeni (Phengodidae) (a). Panel b displays luciferase-expressing E. coli colonies and Panel $\mathbf{c}$, the corresponding emission spectra peaking at the yellow-green $(560 \mathrm{~nm})$ and red $(615 \mathrm{~nm})$ regions. Panel d outlines the mechanism of basic amino acid effect on the partition of excited oxyluciferin into enolate (yellow-green) and keto (red) forms at the luciferase active site. Modified from Viviani et al. (1999). Copyright 1999 American Chemical Society.

of the illuminated termite mounds reveals the presence of Pyrearinus termitilluminans larvae in the mound "windows", exposing the head and shinning prothorax to lure and feed on flying adult termites and other insects (Costa 1982, Costa and Vanin 2010, Redford 1982).

To investigate these insects, the larvae dominium into the termitary was molded with polystyrene. The acquired molds, once extracted, revealed larvae inhabiting a labyrinthine network of tunnels $1-5 \mathrm{~cm}$ deep parallel to the mound surface with individual exits to the outside and an atrium about $1 \mathrm{~cm}$ deep from the exit where they deposit the captured preys for extracorporeal digestion
(Bechara 1988). The strong mandibles of the larva perforate the prey and regurgitate a dark cocktail of proteinases (tripsin) and carbohydrases (amylase, cellulase, $\beta$-glucosidase) whose optimum $\mathrm{pHs}$ lie within 6-8.5, which agrees with the regurgitate $\mathrm{pH}$ of 7.3 (Colepicolo-Neto et al. 1986b).

Pupal P. termitilluminans can also been found inside the termite mounds, and the adult alate insects can be seen flying over the mounds and grass looking for the mate partners. That fertilized females lay eggs on the foot of the mounds is attested by the appearance of a faint green halo surrounding the mound on the soil, produced by thousands of the first instars of larval 


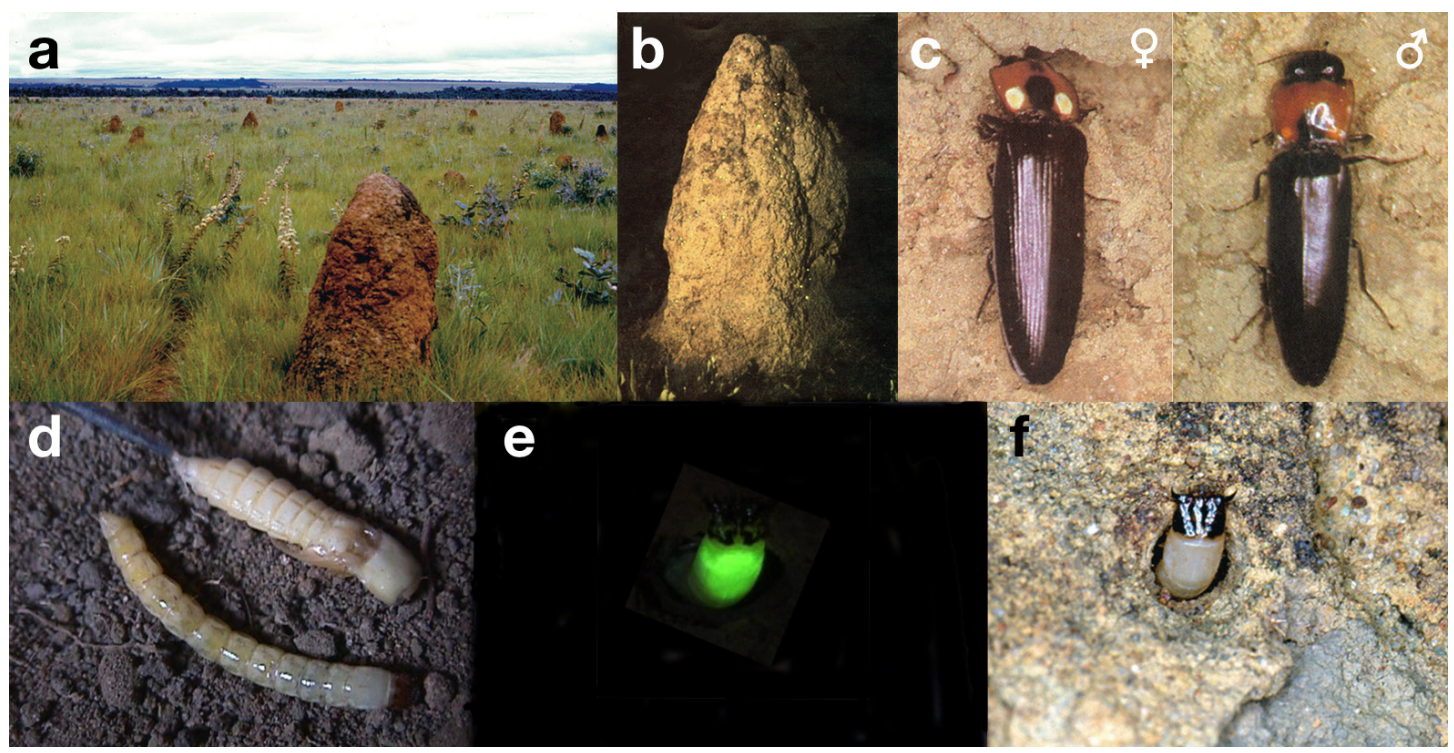

Figure 7 - Photographs of a luminous termite mound (a, b), Pyrearinus termitilluminans adults (c), pupa and larva (d) and a larva emitting green light from the prothorax hunting in the nest tunnel surface exits (e, f). Photos kindly provided by Sergio A. Vanin (IB-USP) and Cassius V. Stevani (IQUSP). Reproduced from Bechara and Viviani (2015). Copyright 2015 Brazilian Chemical Society.

Pyrearinus. These tiny larvae probably feed on the soil microfauna, develop to advanced stages, and excavate their tunnels upwards in a shallow layer of the mound.

The myriad of insects flying around and walking on the luminous termite mound invites other commensals - spiders, millipedes, scorpions, opilliones and frogs - to participate in the banquet offered by the Pyrearinus larvae (Bechara 1988). In turn, these predators are victims of owls and other birds whose excrements contain seeds that nucleate diverse vegetation around the termite mounds.

\section{LUCIFERASE MIGHT COOPERATE WITH ANTIOXIDANT ENZYMES IN REDOX BALANCE}

Molecular oxygen has three main fates in bioluminescent organisms: respiration, generation of activated oxygen (radicals and peroxides), and light emission (Fig. 8).

Metabolic connections among these biochemical routes were first compared by examining larval luminescent and non-luminescent coleopterans (Colepicolo Neto et al. 1986c) by comparing the activities of superoxide dismutase (SOD) and catalase in whole extracts. Luminescent elaterids (Pyrophorus divergens, an unidentified Pyrophorini, Pyrearinus termitilluminans) were found to express SOD activities over six times higher than those in non-luminescent counterparts (Platycrepidus bicinctus, Chalcolepidus zonatus, Ischiodontus sp., Conoderus sp.). Catalase activities were similar in most cases, although 2-4 times higher in both $P$. divergens and unidentified Pyrophorini. Higher SOD activity was measured in P. termitilluminans $(28 \pm 3 \mathrm{U} / \mathrm{mg}$ protein; $\mathrm{n}=10)$ as compared to $8 \pm 2 \mathrm{U} / \mathrm{mg}$ protein in $P$. divergens

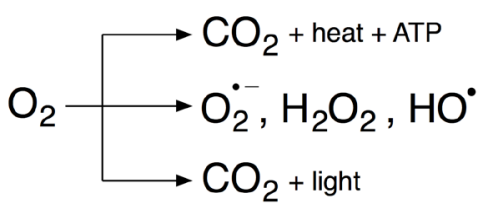

Figure 8 - Biological functions of molecular oxygen in luminescent beetles: mitochondrial respiration to conserve energy as ATP; production of oxyradicals (superoxide and hydroxyl radicals) and $\mathrm{H}_{2} \mathrm{O}_{2}$, involved in oxidative damage and cell signaling (redox control); and bioluminescence. 
( $\mathrm{n}=18)$. It is worth noting that Pyrearinus dwells normally aerated tunnels of the termitaries $\left(\mathrm{pO}_{2}\right.$ $\sim 21 \%$ ) whereas the other species inhabit tunnels excavated in decaying logs $\left(\mathrm{pO}_{2} \sim 2-3 \%\right.$, according to Crowson 1981). A plethora of data reported since the discovery of SOD by McCord and Fridovich (1969) and the investigation of redox defenses in anaerobic, facultative and aerobic organisms in normoxia and hyperoxia demonstrated a positive correlation between $\mathrm{pO}_{2}$ in the tissue, SOD levels and eventually death (Halliwell and Gutteridge 2015). Our hypothesis that luciferases may cooperate with SOD to balance a higher availability of oxygen in the habitat was corroborated by observed two-fold higher SOD activity in the brightest segments of Pyrearinus termilluminans larvae (prothorax and last abdominal segments) as compared to the dim segments (1-8 abdominal segments). These data suggest that bioluminescence may be an auxiliary channel to hamper the possible adverse effect of excess molecular oxygen in luminescent tissues.

To validate the hypothesis of luciferase-SOD partnership in P. termitilluminans larvae to balance their redox status, enzymes of the Krebs cycle (respiration), luciferase (bioluminescence), and SOD and catalase (oxidative stress) were measured in larvae exposed to pure $\mathrm{O}_{2}$ for $72 \mathrm{~h}$ (Barros and Bechara 1998). The prothorax activities of total SOD and mitochondrial MnSOD increased 2- and 3 -fold, respectively, whereas catalase rose $50 \%$, as compared to larvae raised under normoxia. Concomitantly, not only did the levels of luciferase increase by $80 \%$ but luciferin also increased by $50 \%$. The increments in the antioxidant enzymes were interpreted as an adaptive, protective reaction against oxygen toxicity (Figs. 4 and 7). Accordingly, putative indexes of oxidative damage to biomolecules like thiobarbituric acid reactive substances (TBARS) showed significantly augmented lipid peroxidation only in the dim abdomen (30\%), and reduced glutathione was $33 \%$ lower in the thorax. On the other hand, exposure of larvae to hypoxia (2\%
$\mathrm{O}_{2}$ ) drove significant compensatory increases in prothoracic mitochondrial citrate synthase $(85 \%)$ succinate dehydrogenase (25\%), and in the lactate dehydrogenase $(30 \%)$, which is expected from partial anoxia. The luciferase and antioxidant enzyme levels were kept unaltered indicating constitutive levels of Pyrearinus termitilluminans larvae inside the termite mounds. In addition, concomitant hyperoxia and treatment with a luciferase inhibitor, namely the luciferin methyl ester (LME), increased prothorax SOD activity not above 30\% along with higher levels of TBARS (25\%) and protein reactive carbonyl groups $(50 \%)$. Altogether, these data suggest that bioluminescence may have evolved in elaterids as a mechanism to circumvent possible toxic effects of molecular oxygen, mainly in the tracheae, in cooperation with antioxidant enzymes (SOD, catalase) to minimize oxidative imbalance.

The question of how much molecular oxygen is spent for light emission was also worth pursuing through in vivo EPR experiments with paramagnetic lithium phthalocyanine (LiPc) crystallites (Liu et al. 1993). This compound is largely used as a probe to monitor the local $\mathrm{pO}_{2}$ in several biological systems. The higher the microenvironment $\mathrm{pO}_{2}$, the linearly larger is the EPR signal width regardless of $\mathrm{pH}$, temperature and redox conditions.

LiPc microcrystals were injected in a resting, $\operatorname{dim}$ P. termitilluminans larva accommodated in the equipment sample holder, and the EPR signal of the probe $\left(\mathrm{pO}_{2} \sim 112 \mathrm{mmHg}\right)$ was measured for 5 min (Timmins et al. 2000). When a termite worker was offered to the larva mandible, it lit up and the $\mathrm{pO}_{2}$ dropped $18 \%$. Therefore, a considerable fraction of the oxygen inhaled by the larval elaterid is consumed for light production. Moreover, the oxygen diffusion required approximately $600 \mathrm{~ms}$ in the gas phase of the tracheas and $1300 \mathrm{~ms}$ in tissue (aqueous) phase, suggesting that the tracheolar fluid levels control the tissue oxygen levels in larval beetles. 


\section{THE LUCIFERASE ORIGIN OF BEETLE BIOLUMINESCENCE}

The "oxygen detoxification" hypothesis to rationalize the origin of bioluminescence relies on the reported cooperation between luciferase and regulatory antioxidant enzymes in several organisms, mainly bacteria, jellyfish, and fireflies, to minimize oxidative damage during evolution (Wilson and Hastings 2013). The dependence of firefly luminescence on ATP and a high degree of homology of its luciferase with ATPdependent synthetases (ligases), ubiquitous in microorganisms, plants and mammals, led us to test the potential luminogenic effect of luciferin injection into the abdomen of larval Tenebrio molitor (mealworm), a non-luminescent beetle
(Viviani and Bechara 1996). A luciferin and ATP concentration dependent red light emission indeed occurred, and a preliminary physical-chemical study of extracts prepared from the fat body of the larva showed luciferase similarities.

At that time, the Tenebrio luminescent reaction was envisaged as initiated by ligase-promoted adenylation of the carboxyl group of the injected luciferin at costs of ATP such as in acylglycerol and peptide biosynthesis, followed by oxygen addition to the substrate and AMP release, instead of reaction with CoA-SH to form the thioesters precursors of acylglycerides and proteins (Fig. 9). Firefly luciferase was previously employed to develop a chemiluminescence method to analyze carboxylic acids and triacylglycerols in serum

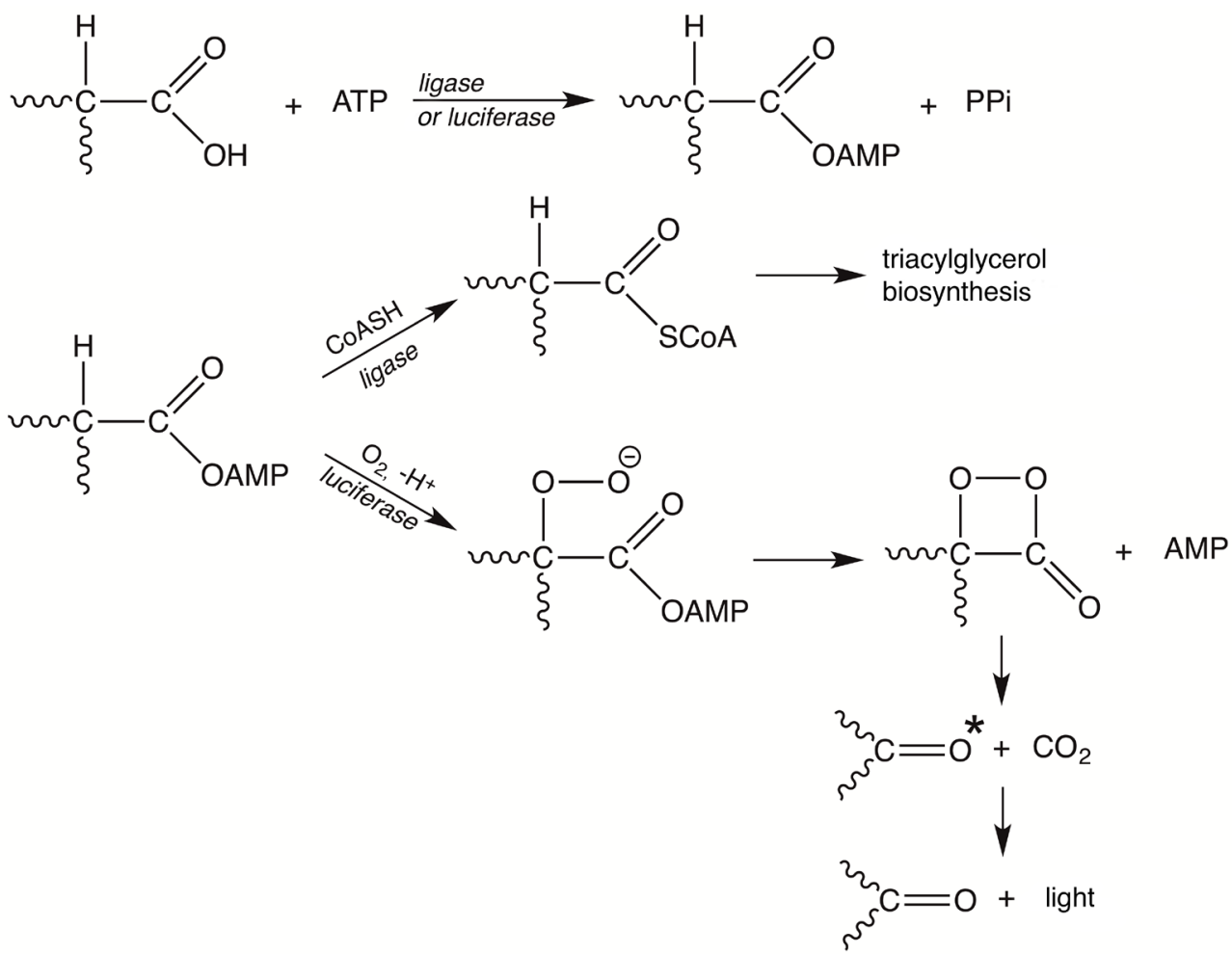

Figure 9 - The putative ligase origin of firefly luciferase. Ligases (ATP-synthetases) catalyze the adenylation of carboxylic metabolites $(\mathrm{RCOOH})$ making reactive mixed anhydride intermediates (RCOOAMP) in microorganisms, mammals and plants. RCOOAMP intermediates are converted by coenzyme A (CoA-SH) into thioesters (R-CSCoA), which are attacked by glycerol to form acylglycerols (fatty acids derivatives) in fats, oils and membrane phospholipids. Conversely, the luciferin adenylate adds molecular oxygen to yield sequentially luciferin hydroperoxide, dioxetanone and electronically excited oxyluciferin, which collapses to the ground state by cold light emission (Fig. 3). 
(Werner et al. 1981). Later, Oba et al. (2003) concluded that indeed the firefly luciferase behaves as an ATP-dependent monooxygenase and a long chain fatty acyl-CoA synthetase.

The cDNA of the luciferase-like ligase was cloned, and the enzyme structure and function determined by Viviani et al. (2013). The authors concluded that luciferases may have evolved from ligases by mutagenesis of amino acids located in the activity site that enable them to act as a luminogenic monoxidase. Mutations of the so-called "protoluciferases" may engender new chemiluminescence-eliciting ligases, capable of using various carboxylic acids as substrates and drawing forth different emission colors (Prado et al. 2011, Viviani et al. 2013). These findings may significantly expand the analytical applications of engineered luciferases and AMP-CoA ligases (Roda 2011, Li et al. 2010, Shimomura 2012).

\section{BIOLUMINESCENCE TECHNOLOGICAL APPLICATIONS}

The upraising of molecular biology boosted the sequencing, cloning and expression of the firefly luc gene and of many other luciferases (e.g., lux from bacteria) and photoproteins (e.g., GFP from the jellyfish Aequorea), which were employed as single or multiple reporter of protein expression in several organisms. A plethora of novel bioand chemiluminescent methods rapidly replaced the expensive and unsafe radioimmunoassays and harnessed, in the following decades, the development of numberless bioassays and bioimaging. The luc gene offers many advantages over other genes in terms of sensitivity (quantum yield $=0.60$ ), low cost and applicability due to the firefly reaction dependence on ATP. At present, there is in principle no obstacle with potent photocounters to measure ATP concentrations in biological, industrial or environmental samples down to attomoles. Theoretically, any impediment would prevent the imaging of cells, tissues and organs affected in experimental animals or infected plants by fungi or bacteria (Nakajima et al. 2010, Roda 2011, Shimomura 2012). Red-emitting beetle luciferases offer additional benefits, allowing the events to be monitored in animals throughout the tissue. The use of firefly luciferase as a primary light to construct quantic CdS (shell)-CdSe (core) nanorods, 20-30 times brighter than the natural light by BRET (Bioluminescence Resonance Energy Transfer), is also worthy to note. By altering the core size and the nanorod length, it is possible to modulate the emission color (blue, green, and red), which turns them into extremely powerful nanosensors for biological systems (Alam et al. 2016), including membrane-associated proteins.

\section{ACKNOWLEDGMENTS}

This work is dedicated to Dr. Cleide Costa (Museu de Zoologia USP, São Paulo), an outstanding Coleoptera expert, for advice in the field and lab work, and long-lasting friendship and cooperation. We thank the Brazilian agencies Fundação de Amparo à Pesquisa do Estado de São Paulo (FAPESP, 2006/056530-4), Conselho Nacional de Desenvolvimento Científico e Tecnológico (CNPq, 306460/2016-5) and Instituto Nacional de Ciência e Tecnologia (INCT, 573530/2008-4)-Redoxoma, as well as the John Simon Guggenheim Memorial Foundation for financial support. We also thank Dr. Erick Bastos and Mr. Timothy Palmer for kindly reading this manuscript. Finally, Etelvino JH Bechara wishes to pay homage to several students and colleagues, most of them co-authors of our articles quoted here, for being key partners in our trajectory across the insect bioluminescence field.

\section{REFERENCES}

ADAM W AND LIU JC. 1972. Alpha-peroxy lactones synthesis and chemiluminescence. J Amer Chem Soc 94: 2894-2895. 
ALAM R, KARAM LM, DOANE DM, COOPERSMITH K, FONTAINE DM, BRANCHINI BR AND MAYE MM. 2016. Probing bioluminescence resonance energy transfer in quantum rod-luciferase nanoconjugates. ACS Nano 10: 1969-1977.

BARROS MPAND BECHARAEJH. 1998. Bioluminescence as a possible auxiliary oxygen detoxifying mechanism in elaterid larvae. Free Radic Biol Med 24: 767-777.

BARTOLONI FH, OLIVEIRA MA, CISCATO LFML, AUGUSTO FA, BASTOS EL AND BAADER WJ. 2015. The chemiluminescence efficiency of catalyzed 1,2-dioxetanone decomposition is determined by steric effects. J Org Chemistry 80: 3745-3751.

BASTOS EL, FARAHANI P, BECHARA EJH AND BAADER EL. 2017. Four-membered ring peroxides: Carriers of chemical energy. J Phys Org Chem 30: e3725.

BECHARA EJH. 1988. Luminescent Elaterid Beetles. In: Advances in Oxygenated Processes, Vol 1. Greenwich: JAI Press Inc., p. 123-178.

BECHARA EJH, BAADER WJ AND STEVANI CV. 2017. Hydrogen peroxide and other peroxides in chemiluminescence, bioluminescence and photochemisty in the dark. In: Vissers MCM, Hampton MB and Kettle TJ (Eds), Hydrogen Peroxide Metabolism in Health and Disease, Boca Raton: CRC Press, Taylor and Francis Group 1: 17-48.

BECHARA EJH AND VIVIANI VR. 2015. Luzes vivas na escuridão: Fatos e Casos. Rev Virtual Quim 7: 3-40.

BITLER B AND MCELROY WD. 1957. Preparation and properties of crystalline firefly luciferin. Arch Biochem Biophys 72: 358-368.

BOYLE R. 1668a. Experiments concerning the relation between light and air in shining wood and fish. Phil Trans 2: 581-600.

BOYLE R. 1668b. Observations and trials about the resemblances and differences between a burning coal and shining wood. Phil Trans 2: 605-612.

BRANCHINI BR, BEHNEY CE, SOUTHWORTH TL, FONTAINE DM, GULICK AM, VINYARD DJ AND BRUDVIG GW. 2015. Experimental support for a single electron-transfer oxidation mechanism in firefly bioluminescence. J Am Chem Soc 137: 7592-7595.

COLEPICOLO-NETO P, BECHARA EJH AND COSTA C. 1986c. Oxygen toxicity aspects in luminescent and nonluminescent elaterid larvae. Insect Biochem 16: 381-386.

COLEPICOLO-NETO P, BECHARA EJH, FERREIRA C AND TERRA W. 1986b. Evolutionary considerations of the spatial organization of digestion in the luminescent predacious larvae of Pyrearinus termitilluminans (Coleoptera:Elateridae). Insect Biochem 16: 811-817.

COLEPICOLO-NETO P, COSTA C AND BECHARA EJH. 1986a. Brazilian species of luminescent Elateridae.
Luciferin identification and bioluminescence spectra. Insect Biochem 16: 803-810.

COLEPICOLO P, PAGNI D AND BECHARA EJH. 1988. Luciferin biosynthesis in larval Pyrearinus termitilluminans (Coleoptera: Elateridae). Comp Biochem Physiol 91B: 143-147.

COSTA C. 1982. Pyrearinus termitilluminans, sp.n., with description of the immature stages (Coleoptera, Elateridae,Pyrophorini). Rev Bras Zool 1, ID 10.1590.

COSTA C. 1997. Bioluminescent Coleoptera. In: Biodiversidade do Estado de São Paulo. Joly CA and Bicudo CEM (Eds). São Paulo: FAPESP.

COSTA C AND VANIN SA. 2010. Coleoptera larval fauna associated with termite nests (Isoptera) with emphasis on the "bioluminescent termite nests" from Central Brazil. Psyche, vol 2010, ID 723947.

COSTA C, VANIN SA, CASARI SA AND VIVIANI VR. 1999. Larvae of neotropical Coleoptera. XXVII Phrixothrix hirtus: immature, neotenic female, adult male and bionomic data (Phengodinae, Phengodidae, Coleoptera). Iheringia Serie Zoologia, Porto Alegre 86: 9-28.

CROWSON RA. 1981. The Biology of the Coleoptera. New York: Academic Press.

DUBOIS R. 1886. Les elaterides lumineux. Bull Soc Zool France 11: 1-275.

GREEN AA AND MCELROY WD. 1956. Crystalline firefly luciferase. Biochem Biophys Acta 20: 170-176.

HALLIWELL B AND GUTTERIDGE JMC. 2015. Free Radicals in Biology and Medicine, $5^{\text {th }}$ Edition. New York: Oxford University Press, 905 p.

HARVEY EN. 1957. A History of Luminescence - From the Earliest Times Until 1900. The American Philosophical Society: Philadelphia, $292 \mathrm{p}$.

KASKOVA ZM, TSARKOVA AS AND YAMPOLSKY IV. 2016. 1001 lights: luciferins, luciferases, their mechanisms of action and applications in chemical analysis, biology and medicine. Chem Soc Rev 45: 6048-6077.

KOO JY, SCHMIDT SP AND SCHUSTER GB. 1978. Bioluminescence of firefly - key steps in formation of electronically excited-state for model systems. Proc Natl Acad Sci USA 75: 30-33.

LALLAB. 1981. Electroretinogram and the spectral sensitivity of the compound eyes in the firefly Photuris versicolor (Coleoptera-Lampyridae): a correspondence between green sensitivity and species bioluminescence emission. J Insect Physiol 27: 461-468.

LALLAB, CRONIN TW, BECHARA EJH, COSTA C AND VIVIANI VR. 2009. Visual ecology of bioluminescent beetles: visual spectra mechanisms and colors of optical signaling in Coleoptera, Elateroidea: Lampyridae. Elateridae and Phengodidae. In: Bioluminescence in Focus - A Collection of Illuminating Essays, Meyer-Rochow VB (Ed), Kerala: Research Signpost, p. 201-228. 
LALL AB, CRONIN TW, CARVALHO AA, SOUZA JM, BARROS MP, STEVANI CV, BECHARA EJH, VENTURA DS, VIVIANI VR AND HILL AA. 2010. Vision in click beetles (Coleoptera: Elateridae): pigments and spectral correspondence between visual sensitivity and species bioluminescence emission. J Comp Physiol A 196: 629-638.

LALL AB, VENTURA DSF, BECHARA EJH, DE SOUZA JM, COLEPICOLO-NETO P AND VIVIANI VR. 2000. Spectral correspondence between visual spectra sensitivity and bioluminescence emission spectra in the click-beetle Pyrophorus punctatissimus (Coleoptera: Elateridae). J Insect Physiol 46: 1137-1141.

LI X, NAKAJIMA Y, NIWA K, VIVIANI VR AND OHMIYA Y. 2010. Enhanced red-emitting railroad-worm luciferase for bioassays and bioimaging. Protein Sci 19: 26-33.

LIU KJ, GAST P, MOUSSAVI M, NORBY SW, VAHIDI N, WALCZAK T, WU M AND SWARTZ HM. 1993. Lithium phthalocyanine: a probe for electron paramagnetic resonance oximetry in viable biological systems. Proc Natl Acad Sci USA 90: 5438-5442.

LLOYD JE. 1978. Insect bioluminescence. In: Bioluminescence in Action, Herring PJ (Ed), New York: Academy Press, p. 241-272.

MCCAPRA F AND RAZAVI Z. 1976. Biosynthesis of luciferin in Pyrophorus pellucens. Chem Commun 5: 155156.

MCCORD JM AND FRIDOVICH I. 1969. Superoxide dismutase. An enzymic function for erythrocuprein (hemocuprein). J Biol Chem 244: 6049-6053.

MCELROY WD. 1947. The energy source for bioluminescence in an isolated system. Proc Natl Acad Sci USA 33: 342-345.

MCELROY WD AND DELUCA M. 1978. Chemistry of firefly luminescence. In: Bioluminescence in Action, Herring PJ (Ed), New York: Academic Press, p. 109-127.

MORAES RB. 1940. Notícia do Brasil Biblioteca Histórica Brasileira, Vol. 16, Pt. 2. São Paulo: Livraria Martins Editora.

NAKAJIMA Y, YAMAZAKI T, NISHI S, NOGUCHI T, HOSHINO H, NIWA K, VIVIANI VR AND OHMIYA Y. 2010. Enhanced beetle luciferase for high-resolution bioluminescence imaging. PLoS ONE 5: e0010011.

NIWA K, ICHINO Y, KUMATA S, NAKASHIMA Y, HIRAISHI Y, KATO D, VIVIANI VR AND OHMIYA Y. 2010. Quantum yields and kinetics of the firefly bioluminescence reaction of beetle luciferases. Photochem Photobiol 86: 1046-1049.

OBA Y, OJIKA M AND INOUYE S. 2003. Firefly luciferase is a bifunctional enzyme: ATP-dependent monooxygenase and a long chain fatty acyl-CoA synthetase. FEBS Lett 540: 251-254.
OBA Y, YOSHIDA N, KANIE S, OJIKA M AND INOUYE S. 2013. Biosynthesis of firefly luciferin in adult lanterns: decarboxylation of L-cysteine is a key step for benzothiazole ring formation in firefly luciferin synthesis. PLoS ONE 8: e84023.

OLIVEIRA AG AND STEVANI CV. 2009. The enzymatic nature of fungal bioluminescence. Photochem Photobiol Sci 8: 1416-1421.

OLIVEIRA AG, STEVANI CV, WALDENMAIER HE, VIVIANI V, EMERSON JM, LOROS JJ AND DUNLAP JC. 2015. Circadian control sheds light on fungal bioluminescence. Cur Biol 25: 964-968.

PRADO RA, BARBOSA JA, OHMIYA Y AND VIVIANI VR. 2011. Structural evolution of luciferase activity in Zophobas mealworm AMP-CoA ligase (protoluciferase) through site-direct mutagenesis in the luciferin binding site. Photochem Photobiol Sci 10: 1226-1232.

REDFORD KH. 1982. Prey attraction as a possible function of bioluminescence in the larvae of Pyrearinus termitilluminans (Coleoptera:Elateridae). Rev Bras Zool 1: 31-34.

RODA A. 2011. Chemiluminescence and Bioluminescence. Past, Present and Future. Cambridge: RSC Publishing, 590 p.

SHIMOMURA O. 2012. Bioluminescence. Chemical principles and methods. Singapore: World Scientific, 496 p.

SHIMOMURA O, GOTO T AND JOHNSON FW. 1977. Source of oxygen in the $\mathrm{CO}_{2}$ produced in the bioluminescent oxidation of firefly luciferin. Proc Natl Acad Sci USA 74: 2799-2802.

TIMMINS GS, BECHARA EJH AND SWARTZ HM. 2000. Direct determination of the kinetics of oxygen diffusion to the photocytes of a bioluminescent elaterid larva, measurement of gas- and aqueous-phase diffusional barriers and modelling of oxygen supply. J Exp Biol 203: 2479-2484.

TRIMMER BA, APRILLE JR, DUDZINSKI DM, JAGACE CJ, LEWIS SM, MICHEL TM, QAZI S AND ZAYAS RM. 2001. Nitric oxide and the control of firefly flashing. Science 292: 2486-2488.

VIVIANI VR. 2002. The origin, diversity, and structure function relationships of insect luciferases. Cell Mol Life Sci 59: 1833-1850.

VIVIANI VR AND BECHARA EJH. 1995. Bioluminescence of Brazilian fireflies (Coleoptera: Lampyridae): Spectral distribution and $\mathrm{pH}$ effect on luciferase-elicited colors. Comparison with elaterid and phengodid luciferases. Photochem Photobiol 62: 490-495.

VIVIANI VR AND BECHARA EJH. 1996. Larval Tenebrio molitor (Coleoptera: Tenebrionidae) fat body extracts catalyze firefly D-luciferin and ATP dependent 
chemiluminescence: a luciferase-like enzyme. Photochem Photobiol 63: 713-718.

VIVIANI VR AND BECHARA EJH. 1997. Bioluminescence and biological aspects of Brazilian railroad-Worms (Coleoptera: Phengodidae). Ann Entomol Soc Amer 90: 389-398.

VIVIANI VR, BECHARA EJH AND OHMIYA Y. 1999. Cloning, sequence analysis, and expression of active Phrixothrix railroad-worms luciferases: relationship between bioluminescence spectra and primary structures. Biochemistry 38: 8271-8279.

VIVIANI VR, HASTINGS JW AND WILSON T. 2002. Two bioluminescent Diptera: the North-American Orfelia fultoni and the Australian Arachnocampa flava. Similar niche, different bioluminescent systems. Photochem Photobiol 75: 22-27.

VIVIANI VR, AMARAL DT, NEVES DR, SIMÕES A AND ARNOLDI FGC. 2012. The luciferin binding site residues C T311 (S314) influence the bioluminescence color of beetle luciferases through main-chain interaction with oxyluciferin phenolate. Biochemistry 52: 19-27.

VIVIANI VR, PRADO RA, NEVES DR, KATO D AND BARBOSA JA. 2013. A route from darkness to light: Emergence and evolution of luciferase activity in AMPCoA-ligases inferred from a mealworm luciferase-like enzyme. Biochemistry 52: 3963-3973.

WERNER M, GABRIELSON DG AND EASTMAN J. 1981. Ultramicro determination of serum triglycerides by bioluminescent assay. Clin Chemi 27: 268-271.

WHITE EH, MCCAPRA F AND FIELD G. 1963. The structure and function of firefly luciferin. J Am Chem Soc 85: 337-343.

WILSON T AND HASTINGS JW. 2013. Bioluminescence - Living lights, lights for living. Cambridge: Harvard University Press, 185 p.

WITTMER W. 1996. Ein weiterer Beitrag zur Kenntnis der Phengodidae (Coleoptera). Rev Bras Entomol 40: 125129. 